Author approved manuscript

Published in: Policing the Urban Environment in Premodern Europe, ed. by Carole Rawcliffe and Claire Weeda (Amsterdam: Amsterdam University Press, 2019)

https://www.aup.nl/en/book/9789462985193/policing-the-urban-environment-in-premoderneurope

ISBN: 9789462985193

\title{
POLICING THE URBAN ENVIRONMENT IN PREMODERN EUROPE
}

edited by

CAROLE RAWCLIFFE and CLAIRE WEEDA 


\section{CONTENTS}

List of Illustrations

List of Figures and Charts

List of contributors

Introduction

Carole Rawcliffe and Claire Weeda

1 Cleanliness, Civility, and the City in Medieval Ideals and Scripts Claire Weeda

2 The View from the Street: The Records of Hundred and Leet Courts as a Source for Sanitary Policing in Late Medieval English Towns

Carole Rawcliffe 
3 Urban Viarii and the Prosecution of Public Health Offenders in Late Medieval Italy G. Geltner

$4 \quad$ Food Offenders: Public Health and the Marketplace in the Late Medieval Low Countries

Janna Coomans

5 Policing the Environment of Late Medieval Dordrecht

Patrick Naaktgeboren

6 Muddy Waters in Medieval Montpellier

Catherine Dubé and Geneviève Dumas

7 Regulating Water Sources in the Towns and Cities of Late Medieval Normandy Elma Brenner

8 Policing the Environment in Premodern Imperial Cities and Towns: A Preliminary Approach

Annemarie Kinzelbach

9 Official Objectives of the Visitatio Leprosorum: Ambiguity, Ambivalence, and Variance

Luke Demaitre

Index 


\section{LIST OF ILLUSTRATIONS}

Front cover: Panorama of Ghent (1534), detail (STAM Ghent)

Frontispiece: Map of towns and cities featured in this volume

1. The value of mountain air illustrated in a fourteenth-century vernacular regimen sanitatis (Naples, Biblioteca Nazionale, MS XIII C 37, fol. 52v)

1.1 The benefits of pure water from a well-illustrated fourteenth-century vernacular regimen sanitatis

(Naples, Biblioteca Nazionale, MS XIII C 37, fol. 63v)

4.1 View of the Fish Market in Leiden (c. 1600), oil on panel by an anonymous artist. The waste bin, which is first mentioned in fifteenth-century records, is depicted to the right of the centre. (Museum de Lakenhal, Leiden)

5.1 Map of the river delta

(H. 't Jong, Tollen en Dordrecht (3); Blog: Apud Thuredrecht;

http://apudthuredrech.nl/?m=201606), last consulted 15 January 2019

5.2 Map of Dordrecht in c. 1600

(Rijksdienst voor het Cultureel Erfgoed, Amersfoort)

6.1 Map of Montpellier in 1665, showing the three hills on which it was built

(Pierre Gariel, Idée de Montpellier: Recherches présentées aux honnestes gens (Montpellier:

Daniel Pech, 1665), annexe, p. 60, bis)

6.2 Location of the most important common wells in medieval Montpellier (background map from Louise Guiraud, 'La ville de Montpellier, ses enceintes et ses faubourgs au Moyen Âge', map no. 1, 1895, Archives municipales de Montpellier, 2Fi441)

6.3 Public fountains in Montpellier in the fifteenth century (background map from Guiraud, Archives municipales de Montpellier, 2Fi441) 
7.1 Engraving of the fountain of Saint-Maclou, Rouen, by Polyclès Langlois, dated 1835

(Rouen, Bibliothèque municipale, Est. topo. g 4199)

7.2 Plan of the course of the Gaalor water source, showing (top centre) the priory church of Saint-Lô with its fountain, in the Livre des fontaines of Jacques Le Lieur, completed in 1525 (Rouen, Bibliothèque municipale, MS G3)

8.1 Ruined leprosy complex with tree stumps, Nördlingen, 1647

(Stadtarchiv, Nördlingen, Salbuch Johannis Pflege) 


\title{
CHAPTER ONE
}

\section{Cleanliness, Civility, and the City in Medieval Ideals and Scripts ${ }^{1}$}

\author{
Claire Weeda
}

\begin{abstract}
Latin and vernacular urban panegyrics, describing the ideal city and its residents, mushroomed in the twelfth century. Painting a utopian view of the city that mirrors the heavenly Jerusalem, they rhetorically conveyed ideals of urbanity for aspiring members of the body politic to emulate. This chapter explores the ways in which the cityscape constructed in these texts, and residents' behaviour (as influenced by conduct manuals and regimes of health), appear embedded in a natural environment reflected through the lens of Galenic medicine. Evoking the benefits of cleanliness and beauty, these concepts of health and hygiene accorded closely with issues of social status. The disciplined quest for moderation and balance offered spiritual and physical health, as well as enhanced personal repute.
\end{abstract}

Key words: Galenic medicine; panegyrics; urbanity; habitus; hygiene

Florence's salubriousness in Leonardo Bruni's Laudatio Florentinae urbis, written about 1404 , stands in stark contrast to today's image of the medieval city as a place mired in filth. ${ }^{2}$ Ideally situated between mountains and a valley, the city was shielded from the bitterly cold northern winds and the corrupt air that festered in the damp and dreary vale. Beneath a canopy of fresh air, the circuit of well-maintained walls enveloped a majestic cityscape of palaces and churches, ancient and modern. Above all, Florence surpassed all other cities in its cleanliness, for 'you will find here nothing that is disgusting to the eye, offensive to the nose, or filthy under foot. The great diligence of its inhabitants ensures and provides that all filth is removed

\footnotetext{
${ }^{1}$ For this publication I received research support from 'Healthscaping Urban Europe' (European Research Council grant no. 724114). I would like to thank Joris van Dijk for his editorial assistance.

2 The dating of Bruni's Laudatio is discussed in Hankins, Plato in the Italian Renaissance, II, pp. 367-378.
} 
from the streets, so you see only what brings pleasure and joy to the senses. ${ }^{3}$ Sanitation penetrated the very pores of the city, purging the nooks and crannies of the household interiors of the poor and the rich, as well as sweeping clean the broad, paved streets where crowds gathered. Refuse produced at night was not left lying about in the streets, as in other cities, but removed directly. Perambulation of the city was further facilitated through the channelling of rain water in gutters, thereby ensuring that pedestrians had dry feet. As a result, 'just as these citizens surpass all other men by a great deal in their natural genius, prudence, elegance and magnificence, so the city of Florence has surpassed all other cities in its prudent site, and its splendour, architecture, and cleanliness'.

In the past, scholars have often viewed Bruni's panegyric of Florence - which goes on to describe the orderliness of the city's institutions and laws - first and foremost as a rhetorical blueprint for civic humanism. The text is thus said to reflect classical, Ciceronian ideals of civic culture, language, and politics rather than the actual concerns, practices, and material conditions of the late medieval city. ${ }^{5}$ More generally, scholars such as Frugoni and Scattergood have regarded medieval urban encomia - the genre to which Bruni's description praising the city belongs - as idealized pictures of an enclosed space of Christian spirituality, which alluded to a divine sanctuary or even a heavenly Jerusalem. ${ }^{6}$ In this chapter, however, I would like to examine encomia from a different angle, namely one involving ideas of urban cleanliness, the undergirding impact of Greek-Arabic medical knowledge, and civic honour. Greek-Arabic medical knowledge, a discourse concerning physical and spiritual wellbeing, was disseminated across western Europe from the 1100s in various formats, including medical

\footnotetext{
${ }^{3}$ Bruni, Laudatio Florentinae urbis, ed. Baron, I, p. 235; trans. Kohl, The Earthly Republic, p. 138: '[I]n qua nichil fedum oculis, nichil tetrum naribus, nichil pedibus sordidum offendas. Summa diligentia habitatorum cuncta eiusmodi cauta ac provisa sunt ut, omni turpitudine procul semota, ea tantum incurras que letitiam ac iocunditatem sensibus queant afferre.'

${ }^{4}$ Bruni, Laudatio Florentinae urbis, ed. Baron, I, p. 233; trans. Kohl, The Earthly Republic, p. 136: 'Nam quemadmodum ipsi cives naturali quodam ingenio, prudentia, lautitia et magnificentia ceteris hominibus plurimum prestant, sic et urbs prudentissime sita ceteras omnes urbes splendore et ornatu et munditia superat.' ${ }^{5}$ For instance, Biow, in The Culture of Cleanliness, pp. 87-94, argues that Bruni's commentary on Florentine hygiene should be interpreted foremost as a metaphor for linguistic purity. The discussion about reality versus rhetoric in Bruni's Laudatio goes back to a debate of 1966 in the journal Past \& Present between Hans Baron ('Leonardo Bruni: “Professional Rhetorician” or “Civic Humanist”?'), who argued that Bruni’s description reflected political reality in Florence, and Jerrold Seigel ('Civic Humanism or Ciceronian Rhetoric?'), who emphasized the rhetorical nature of Bruni's words.

${ }^{6}$ Frugoni, Distant City, pp. 10-12, 20; Scattergood, 'Misrepresenting the City', p. 23.
} 
treatises, regimens and urban statutes, and by using various modes of communication, such as educational texts, conduct books, sermons, public announcements, and the infrastructure of public space. ${ }^{7}$ Texts discussing Galenic theory postulated that a person's health was subject to the influence of the so-called six non-naturals - external agents such as the quality of the air, dietary intake, and rest - on the body's constitution, in which the absorption of images and odours through the sensory organs played a significant part. ${ }^{8}$ Civic councils, as well as individual residents, accordingly went to some lengths to sanitize streets, waterways, and human bodies in response to medical concerns over the impact of bad smells on the vital spirits (miasma theory) and sights on the nervous system (intromission theory), thereby removing 'matter out of place' and enhancing their city's beauty. ${ }^{9}$ Medieval historians have, indeed, recorded an array of urban health interventions that in part were underscored by medical theory, at a private and public level, across Europe's cities from the twelfth century onward, from individual adherence to regimens to the installation of public waste disposal

\footnotetext{
${ }^{7}$ For the concept of the 'regime of truth', see Foucault, 'Political Function of the Intellectual'. For the spread of Galenic knowledge in the Latin West from c. 1100, see: Demaitre, Medieval Medicine, pp. 1-34; Siraisi, Medieval and Early Renaissance Medicine, pp. 48-77; McVaugh, Medicine before the Plague, pp. 68-107. In
} 'The Politics of Cleanliness', pp. 82-83, Biow does acknowledge that in the late Middle Ages concerns over public health, and particularly the establishment of health boards, increased in response to outbreaks of plague, yet he argues that there was little medical reasoning behind sanitary regulations, and still considers Bruni's panegyric to be first and foremost a rhetorical argument for cultural-political humanist ideals. Conversely, as Cohn, Cultures of Plague, for instance, argues (although likewise viewing the introduction of public health regulations as a reaction to the Black Death), learned physicians trained in medical theory played a significant role in establishing sanitary regulations in late medieval cities.

${ }^{8}$ Rather, 'Six Things Non-Natural', pp. 337-347; García-Ballester, 'On the Origins of the Six Non-Natural Things', pp. 105-115; Mikkeli, Hygiene, pp. 19-23; and pp. 18-23 above.

${ }^{9}$ See Geltner, 'Finding Matter Out of Place', p. 307, and Fasoli, 'La coscienza civica nelle Laudes civitatum', for the importance of the theme of decus in the urban panegyric. For sanitary efforts, see Ciecieznski, 'The Stench of Disease'; Henderson, 'Public Health, Pollution and the Problem of Waste Disposal', pp. 378-379; and the publications mentioned in note 6 above. See Jørgensen, 'Cooperative Sanitation', pp. 554-558, for collective efforts to sanitize the environment. For a summary approach to cleanliness in the Middle Ages, see Vigarello, Concepts of Cleanliness, and Ashenburg, The Dirt on Clean. For the established bathing culture and concepts of moral cleanliness in the later Middle Ages, see Coomans and Geltner, 'On the Street and in the Bathhouse', pp. 9-18. Bocchi, 'Regulation of the Urban Environment', p. 74 and note 64, describes measures in Siena concerning the Piazza del Campo and the preservation of urban beauty. 
systems, the appointment of officials policing the environment, and the prosecution of offenders, as described in the rest of this volume. ${ }^{10}$

A hitherto relatively unexplored question, however, is to what extent medical theory informed ideals concerning the urban environment and civic behaviour in encomia produced in the central and later Middle Ages. How might city dwellers have been encouraged to subject themselves to these medical discourses, take heed of sanitary directives, and selfpolice their behaviour, inspired by the broadcasting of such models of cleanliness and health through the medium of urban panegyrics and conduct books? And how were these ideals of cleanliness connected with notions of urbanity, good Christian behaviour, and, ultimately, incorporation within the body politic and its deliberative institutions, such as city councils? These are pertinent questions, given that the premodern city was said to be defined by the morality and sense of identity of its inhabitants - civitas in civibus. To answer them, it is therefore useful to first make a short excursion into the disciplines of sociology and anthropology, in order to understand how concepts of health, hygiene, civility, and morality might go hand in hand.

\section{Physical and socio-cultural capital: discipline and moderation}

The idea that healthy and hygienic behaviour and care for the environment might not only promote physical wellbeing but also bestow a higher level of social status can already be inferred from the early twelfth-century conduct book Disciplina clericalis, compiled by the Spanish physician Petrus Alphonsi, who observed that hand-washing after dinner was both 'phisicum et curiale' ${ }^{11}$ His comment suggests that the acquisition and expenditure of socio-

\footnotetext{
${ }^{10}$ The following overview is by no means exhaustive. See also Rawcliffe, Urban Bodies; Rawcliffe, 'Sources for the Study of Public Health'; Magnusson, 'Medieval Urban Environmental History'; Keene, 'The Medieval Urban Environment'; Geltner, 'Public Health and the Pre-Modern City'; Thorndike, 'Sanitation, Baths and Street-Cleaning'. For London: Sabine, 'City Cleaning in Mediæval London'; for Italy: Bocchi, 'Regulation of the Urban Environment'; for the appointment of officials overseeing compliance with environmental legislation: Geltner, 'Finding Matter Out of Place'; Geltner, 'Urban Viarii and the Prosecution of Public Health'; Kwakman, 'Slijkburgers in Utrecht'.

${ }^{11}$ Petrus Alphonsi, Disciplina clericalis, ed. Hilka and Söderhjelm, XXVI, p. 40. For the popularity of the Disciplina clericalis, see Tolan, Peter Alfonsi and his Medieval Readers, pp. 73-91, and Appendix 3, pp. 199204, for a list of manuscripts. That hygiene and status went hand in hand is echoed in the rubric 'Phisica urbanus' added to the medical section of Daniel of Beccles' conduct book Urbanus magnus. I am indebted to Fiona Whelan for this information: Whelan, The Making of Manners and Morals in Twelfth-Century England.
} 
cultural capital - courtliness or urbanity (civilitas, curialitas, urbanitas) ${ }^{12}$ - was tied to the possession of physical capital - health and hygiene (phisicum) - which might be acquired and embodied (as habitus) through the adoption of health-giving practices, to use the terminology coined by Pierre Bourdieu. Similar recommendations, indicating that Alphonsi's observation was not exceptional, can be found in various contemporaneous tracts on courtly behaviour and in medical treatises that contain passages about desirable social conduct, for instance commenting that silence at the dinner table was both healthy and civilized. ${ }^{13}$ In a wider context, it might be added that attributes associated with civility were often related to health: youth, a healthy radiance, and an unblemished, fair skin are in many sources seen as physical manifestations of courtliness, civility, and Christianity - and ultimately purity. ${ }^{14}$

As this chapter suggests, the linchpin connecting such idealized images of behaviour and emotions regarding the self to the wider urban environment was (self-)discipline and moderation, implying control over the generation of odours, the evacuation of potentially shame-inducing bodily superfluities (for instance sweat, urine, or faeces) and the care spent on maintaining a clean environment, such as sweeping streets or cleansing ditches. Images of cleanliness thus evoked notions of self-discipline, order, and control, both over the physical and moral self, and over the physical environment. Inversely, 'rustic' or 'immoral' behaviour might be associated with low social status, lack of discipline, dirt, and ill-health, although this in part depended on a person's station at birth - for unhygienic behaviour, ugliness, or sexual promiscuity in the case of the nobility was less likely to be accepted as evidence of social inferiority. $^{15}$

\footnotetext{
${ }^{12}$ With the disintegration of the late Roman Empire, the ideal of curialitas and urbanitas - civilized behaviour lost its urban context, and in the tenth and eleventh centuries was usually employed in the context of the schools run by royal courts: Gillingham, 'From Civilitas to Civility', p. 283. However, as Zotz has argued in 'Urbanitas in der Kultur des westlichen Mittelalters', pp. 307-308, with the onset of urbanization in the twelfth century, the terms urbanitas and civilitas regained their sense of civilized 'urban', alongside courtly, habitus.

${ }^{13}$ Pels (ed.) and Hofstede (trans.), Pierre Bourdieu, Opstellen over smaak, habitus en het veldbegrip. In Bourdieu's work, habitus stands for the cultural dispositions of the elite which give access to the symbolic capital of power and impose order (in which the elite holds a dominant position): Bourdieu, Distinction, pp. 2324. See Weeda, 'Reviewing Conduct Books', for source references concerning health and hygiene in twelfthand thirteenth-century conduct books.

${ }^{14}$ See, for instance, Epstein, Purity Lost, Chapter one.

${ }^{15}$ Coudert, 'Sewers, Cesspools, and Privies', pp. 716-717. Cleanliness, the use of soap, and access to bathing facilities might also point towards economic prosperity: Van Dijk, 'Soap Is the Onset of Civilization', p. 3.
} 
Taking a bird's eye view, it can be argued that the possession of physical capital further helped to rank individuals with reference to accepted socio-cultural and religious categories, thereby allowing them to position themselves and gain (or contest) social and political status in the cityscape through self-disciplining the body, behaviour, and emotions. Indeed, as Mary Douglas argued: 'The care that is given to [the body], in grooming, feeding and therapy, the theories about what it needs [...] must correlate with categories in which society is seen in so far as these draw upon the same culturally processed idea of the body' categories which may be ordered hierarchically. ${ }^{16}$ City dwellers of a higher station could thereby, in the pursuit of physical and socio-cultural capital, take recourse to scripts offering advice on how to maintain high standards of personal hygiene and acquire 'civilized manners', or habitus, as laid down in books of conduct such as that produced by Petrus Alphonsi. $^{17}$

In order for ideals of health, civility, and morality to become relevant to the wider urban population, it was, however, necessary that they should be held up to everyone as a standard to emulate. To understand how such ideals, especially of wellbeing and cleanliness in relation to concepts of Christian and 'civilized' behaviour, may have been presented to urban communities, I have scoured eighteen Latin urban encomia (excluding Bruni's text), stretching from the eighth century to the turn of the fourteenth century (six of which date from before 1000), for references to the natural and material environment, hygiene, and appropriate religious and civic behaviour. ${ }^{18}$ The panegyrics in question, straddling the central Middle Ages and the outbreak of the Black Death, were for the most part produced in Italy (thirteen), with England (three) trailing far behind, and France in third place (two). ${ }^{19}$ At the outset, it must be emphasized that these texts present ideal constructions of urban reality and of the conduct of the populace as advocated by members of the elite. ${ }^{20}$ As such, the models of good

\footnotetext{
${ }^{16}$ Douglas, Natural Symbols, p. 93.

${ }^{17}$ Nederman, 'Nature, Ethics, and the Doctrine of "Habitus"'. See Weeda, 'Reviewing Conduct Books', for references to literature on the topic.

${ }^{18}$ These sources are drawn from Hyde, 'Medieval Descriptions of Cities', pp. 338-340. See also the bibliography of primary printed sources at the end of this chapter.

${ }^{19}$ In the late Middle Ages, the German Territories witnessed a surge in the production of urban encomia, but they fall outside the scope of this chapter.

${ }^{20}$ In "“All Good Rule of the Citee"”, pp. 302-304, when discussing sanitation in late medieval Coventry and Norwich, Dolly Jørgensen describes how magistrates strove to work for the common weal or common good, as
} 
behaviour described in these texts were presumably tailored to reinforce the elite's status and were perhaps only accessed by the elite, supplemented by visual images and literary prose. ${ }^{21}$ The question therefore remains as to what extent the acquisition of status through selfdiscipline was actually attainable by, or even desirable to, the great majority of urbanites in a hierarchically ordered society. ${ }^{22}$ As many contributions to this volume attest, environmental regulations and beliefs about health and hygiene could be, and were often, ignored or resisted at all levels of urban society for many reasons, including apathy, ignorance, political conflicts, and financial incentives. Ideals and practices might thus stand far apart for a myriad of reasons.

\section{Idealized cityscapes, environments, and civility}

Between the eighth and early-fifteenth century, intellectuals - mostly clerics who often resided at ecclesiastical or secular courts, but also laymen working in an urban environment produced dozens of idealized descriptions of the city known as urban encomia (panegyrics, laudes urbium $){ }^{23}$ Although they constituted a rather disparate genre, these panegyrics commonly drew upon the tradition of late antique epideictic oratory, which taught authors to comment on the physical setting, infrastructure, founders, and laws of cities, as well as the characteristics of their inhabitants. Early examples include Ausonius' fourth-century Ordo urbium nobilium. The genre was continued in the early Middle Ages, but the descriptions were now infused with religious beliefs and dominated by the task of painting an idealized

well as promoting 'civic godliness'. See further note 73 below for literature on the common good in political theory.

${ }^{21}$ As succinctly summarized by Turning, Municipal Officials, p. 9, and Bourdieu, Outline of a Theory of Practice, pp. 90-91, 160-163. However, these ideals presumably resonated amongst, and were shaped by, at least a section of urban society in order for them to appear relevant. They cannot therefore have been wholly academic.

${ }^{22}$ Rawcliffe, Urban Bodies, 78-83. In the later Middle Ages, the urban community was conceived as a body politic, made up of social groups who were expected to cooperate in harmony, yet each in accordance with its own station in society: see note 95 below.

${ }^{23}$ The genre of the urban panegyric is discussed in Hyde, 'Medieval Descriptions of Cities'; Ruth, Urban Honor in Spain; Classen, Die Stadt im Spiegel der 'Descriptiones' und 'Laudes Urbium'; Schmidt, 'Societas Christiana in civitate'; Zanna, “"Descriptiones urbium”"; Frugoni, Distant City, pp. 54-81. 
Christian cityscape, potentially representing 'Jerusalem', and stressing the devotion of its populace. $^{24}$

Tending to grow longer over the course of time, the products of this genre encompassed both poetry and prose. Allusions and comparisons to the illustrious forebears Athens and Rome were not uncommon in the laudes, in an attempt to celebrate the ancient history or features of cities. ${ }^{25}$ It is not, however, possible to discern a clear chain of transmission of the texts, except in the case of Milan, where an eighth-century Lombard manuscript containing the De laudibus urbium may have presented a blueprint of sorts for later Milanese laudes. ${ }^{26}$ The genre gained distinct popularity from the twelfth century onwards with the acceleration of the process of urbanization, particularly in Italy. ${ }^{27}$ From this period the descriptions become more detailed, extending from climate and the religious landscape to government institutions and urban occupations. William Fitzstephen's Descriptio nobilissimi civitatis Londoniae (written between 1170 and 1183) thus advertises London's famous landmarks, such as St Paul's cathedral, the Tower of London and Westminster Palace, as well as celebrating the city's wealth and commerce, its cook shops, sports, and schools. ${ }^{28}$ Later medieval encomia more frequently also stand by themselves as discrete examples of rhetorical writing - reflecting a burgeoning civic pride - whereas earlier examples mostly feature as short excursions in urban chronicles or poetry.

Although the encomia reflect ideals, this does not necessarily mean that they were entirely devoid of real concerns over the environment and health. According to J.K. Hyde, the information garnered for writing the city panegyric was drawn in part from municipal charters, privilegia, catalogues of shrines, and ecclesiastical ordinances, and, especially in the later Middle Ages, from administrative records. ${ }^{29}$ Notably, Fitzstephen's Descriptio nobilissimi civitatis Londoniae, initially inserted at the beginning of his biography of Thomas Becket, in the fourteenth century was transcribed in a copy of the Liber custumarum, a collection of civic ordinances containing advice on good government produced by the

\footnotetext{
${ }^{24}$ Scattergood, 'Misrepresenting the City', pp. 22-24.

${ }^{25}$ For instance, William Fitzstephen claims that London predated Rome in antiquity: Descriptio nobilissimi civitatis Londoniae, ed. Robertson, III, pp. 7-8.

${ }^{26}$ Hyde, 'Medieval Descriptions of Cities', pp. 312-317.

${ }^{27}$ Fasoli, 'La coscienza civica nelle Laudes civitatum'; Frugoni, A Distant City, pp. 54-81.

${ }^{28}$ William Fitzstephen, Descriptio nobilissimi civitatis Londoniae, ed. Robertson, III, pp. 3-5, 8.

${ }^{29}$ Hyde, 'Medieval Descriptions of Cities', pp. 311, 324, 327.
} 
fishmonger and city chamberlain Andrew Horn (c. 1275-1328). ${ }^{30}$ On the other hand, Latin grammarian Bonvesin de la Riva's detailed description of Milan, De magnalibis Mediolani, dated to 1288, was in his own words intended to inform both foreigners and the Milanese of the city's magnificent attractions, and thus seems to represent an early example of a city guide. At the other end of the spectrum, Lucian's twelfth-century De laude Cestrie, whose street plan took the form of a cross, is replete with religious symbolism and probably served a rhetorical-contemplative function reminiscent of the pilgrim guides to Rome and Jerusalem. ${ }^{31}$ Thus, these encomia served multifarious purposes stretching beyond mere outbursts of civic pride. $^{32}$

Comments in these sources bearing upon public health may be broken down into two categories: remarks pertaining first to man-made infrastructure and to the natural environment; and second to the residents' hygienic, 'civilized' behaviour, although overlap occurs where civic councils sought physically to modify the natural environment, particularly in the case of water management. In the following paragraphs I will review these comments, considering the extent to which they expose concerns over public health and refer implicitly or explicitly to Galenic theory. I shall begin with descriptions of human interventions regarding the construction and upkeep of urban infrastructure.

It is significant that throughout the entire period under review both the Italian and English panegyrics comment conspicuously on the structure of city walls and turrets: edifices which were seen to safeguard the population from external threats and to affirm civic-religious identity. These observations refer back to ancient rhetorical descriptions of the pagan city, yet are enhanced with additional meaning, as walls might from early medieval times be viewed as a Christian symbol of circular perfection, offering spiritual protection against physical and moral dangers. ${ }^{33}$ Following the same Classical tradition, various later medieval encomia on

\footnotetext{
${ }^{30}$ Rawcliffe, Urban Bodies, pp. 82-83. Horn's biography may be found in Catto, 'Andrew Horn', pp. 387-390.

${ }^{31}$ Lucian of Chester, De laude Cestrie, ed. Taylor, pp. 46-57; Rawcliffe, Urban Bodies, pp. 91-93; Hyde, 'Medieval Descriptions of Cities', p. 325. See Carruthers, Craft of Thought, for spatial descriptions of sacred locations as a tool for meditation.

${ }^{32}$ Unfortunately, to date, relatively little research has been conducted on the audience for, and possible performance of, the texts, which would shed more light on their functionality.

${ }^{33}$ As stated by Bonvesin de la Riva, De magnalibus Mediolani, ed. Pontiggia, p. 40. See Bocchi, 'Regulation of the Urban Environment', p. 68; and, for the concept of the encircled city as an urban ideal, Scattergood, 'Misrepresenting the City', p. 49. See also Laudes Mediolanensis civitatis, ed. Dümmler, I, p. 25; Laudes
} 
Milan and Florence likewise praise the well-ordered street planning, together with the spacious market squares and palaces, public spaces maintained by the citizens through the payment of property taxes. ${ }^{34}$ Thus, a Florentine panegyric of 1339 states that the city is 'full of palaces of the best stone, both the communal and private properties', including those occupied by the municipal government and judiciary. ${ }^{35}$ From the early Middle Ages, the quality of street paving and use of flint stone in some Italian cities also attract favourable attention. ${ }^{36}$ These references to the built-up environment, drawing upon ancient models, do not specifically allude to medical theory and are commonplace. Nonetheless, they already divulge an active sense of the importance and benefits of a well-maintained urban infrastructure, which incorporated buildings assigned to civic administrative bodies.

Despite the multifarious and serious efforts by later medieval urban governments to banish obnoxious odours and unseemly sights from public spaces, for instance by covering up gutters and cesspits and installing public latrines, relatively little attention is paid directly to urban sewerage in any of the encomia. ${ }^{37}$ Moreover, on the two occasions in urban panegyrics where sewerage is actually mentioned, it occurs within the context of the inheritance of Roman infrastructure. Thus, William Fitzstephen, boasting of London's seniority to Rome and comparing its judicial and administrative institutions to the ancient city's, merely notes that London had 'drains and aqueducts in its streets', ${ }^{38}$ in a period when the Assize of

Veronensis civitatis, ed. Dümmler, I, p. 119; William Fitzstephen, Descriptio nobilissimi civitatis Londoniae, ed. Robertson, III, pp. 2, 3; Lucian of Chester, De laude Cestrie, ed. Taylor, pp. 45-46, 49; Opicinus de Canistris, Liber de laudibus civitatis Ticinensis, ed. Maiocchi and Quintavalle, p. 18; Florentie urbis et reipublice descriptio, ed. Frey, p. 119.

${ }^{34}$ Bonvesin de la Riva, De magnalibus Mediolani, ed. Pontiggia, p. 36; Florentie urbis et reipublice descriptio, ed. Frey, p. 120. See also Bocchi, 'Regulation of the Urban Environment', p. 68.

${ }^{35}$ Florentie urbis et reipublice descriptio, ed. Frey, p. 120: 'Hec civitas quasi tota plena palatiis de optimo lapide ac communibus et inferioribus domibus.'

${ }^{36}$ Laudes Mediolanensis civitatis, ed. Dümmler, I, p. 25; Laudes Veronensis civitatis, ed. Dümmler, I, p. 120. Jørgensen, ‘Cooperative Sanitation’, pp. 551-553, states that paving was not uncommon in England, particularly from the thirteenth century onward, although in York, for instance, side streets were already paved with cobblestones by the twelfth century at least.

${ }^{37}$ Bocchi, 'Regulation of the Urban Environment', p. 73; Balestracci, 'The Regulation of Public Health', p. 346; Jørgensen, 'Modernity and Medieval Muck'; and the numerous examples of efforts to control obnoxious smells and sights in references in note 6 , above.

${ }^{38}$ William Fitzstephen, Descriptio nobilissimi civitatis Londoniae, ed. Robertson, III, p. 8: 'eluviones et aqaeductus in vicis'. 
Buildings was already laying down detailed regulations for the location of private cesspits. ${ }^{39}$ An encomium dating from about 1330, and attributed to Opicinus de Canistris, similarly recalls Pavia's marvellous vaulted sewerage system, claiming that its subterranean passages were high enough for a person to pass along seated on a horse. ${ }^{40}$ Nonetheless, despite the fact that, for example, Milanese statutes of the fourteenth century endeavoured to control the disposal of waste that might make 'the air diseased', the panegyrics remain relatively silent on such interventions in the material infrastructure. ${ }^{41}$

Aside from the excerpt from Leonardo Bruni's panegyric presented above, only three encomia comment directly on the cleanliness of the built-up environment. These all date to the fourteenth century, perhaps reflecting growing concerns in this period about hygiene in response to the wider dissemination of Galenic theory. Parisian scholastic philosopher Jean de Jandun, companion to the medically-trained philosopher Marsilius of Padua during his sojourn at the court of Louis of Bavaria in 1326, comments in his laudes of Paris (dated to 1323 ) that the city is clean (propitius) and admired by all men of good will. ${ }^{42}$ In addition, when praising Senlis, where he occupied a prebend, he goes on to observe that 'generally none of the city pavements are stained with unsightly dirt, but are all of them levelled off, spotless and clean'. ${ }^{43}$ In a panegyric to Florence, dated to 1338 , Giovanni Villani likewise claims that it has become neater, more beautiful, and healthier. ${ }^{44}$

In aggregate, relatively little is said about the built urban environment in medieval encomia in relation to hygiene, and where it is mentioned the comments allude in part to ancient tradition. Far more attention, however, is lavished on the natural environment and its potential benefits or risks to public health. In comparison, at least twelve of the eighteen texts

\footnotetext{
${ }^{39}$ They were to be located at least two-and-a-half feet away from a neighbour's land: see Shaw, 'The Construction of the Private in Medieval London', pp. 452-453.

${ }^{40}$ Opicinus de Canistris, Liber de laudibus civitatis Ticinensis, ed. Maiocchi and Quintavalle, p. 20: 'Totius civitatis tam strate, quam latrinarum cuniculi, quibus omnes domus habundant, tempore pluvial per subterraneas et profundas cloacas emondantur, que omnes cloace cum testudinibus quasi pulcra hedificia sunt sub terra, et alicubi tam altas testudines habent, sue fornices, ut posit per eas equus cum sessore transire.' See Rawcliffe, Urban Bodies, pp. 140-147.

${ }^{41}$ Bocchi, 'Regulation of the Urban Environment', p. 73. For the construction of underground channels in Florence in the fourteenth century, see Balestracci, 'The Regulation of Public Health', p. 346.

${ }^{42}$ Inglis, 'Gothic Architecture and a Scholastic', pp. 63-64.

${ }^{43}$ Jean de Jandun, Tractatus de laudibus Parisius, ed. Le Roux de Lincy and Tisserand, pp. 62, 76: '[P]avimenta civitatis nulla fere lutorum turpitudine maculate sint, sed plana, pura et munda per totum.'

${ }^{44}$ Villani, Cronica, ed. Racheli, I, 38, p. 20. Reference drawn from Frugoni, Distant City, pp. 59-60.
} 
considered here remark, often extensively and explicitly, on the geographical situation of cities (on hilltops, in mountainous regions, or river valleys) - which is in keeping with Hippocratic ideas set out in texts such as Airs, Waters, and Places - and the access to natural resources hunted or harvested in their vicinity. ${ }^{45}$ Often mentioned are the woodlands and fertile meadows yielding grain, vegetables, fruits, wine, meat, and wool. Many texts also emphasize a city's situation on river banks, stressing its proximity to fresh water and the abundance of fish. Thus, in 780 Alcuin observes that in York the Ouse's waters are teeming with fish. ${ }^{46}$ In 1195 , Lucian likewise praises Chester for its great catch of fish, although adding that many fishermen who cast their nets on the sands at low tide, possibly as a result of local overfishing, had lost their lives. ${ }^{47}$ Finally, circa 1330 , in the encomium to Pavia attributed to Opicinus de Canistris, the author relishes the summertime abundance of sturgeon and crayfish, even staking the claim that the fish in the river Ticino were the healthiest and best in the whole of Lombardy. ${ }^{48}$

A supply of clean water is assuredly one of the most important preconditions for the survival of an urban population; and great value was accordingly placed on it. In the thirteenth century, Bonvesin de la Riva stated that six particulars set Milan apart from other cities, the first of which was the abundance of high-quality water, besides its archiepiscopal dignity and the impressive number of scholars in the college of jurists. ${ }^{49}$ Clean water was essential for drinking and cooking, for sustainable fishery, and food production, as well as for transport, effective sanitation, waste disposal, and the support of industries such as dyeing and brewing. Accordingly, from the early Middle Ages, access to water and the shared ownership of wells had not only been a potential source of conflict but also of neighbourliness; and questions were often raised over the public or private nature of water resources. ${ }^{50} \mathrm{We}$ see these concerns reflected both in the encomia and in regulations and official interventions in the later Middle Ages, many of which focused on maintaining the free flow of water, forbidding uncontrolled waste disposal in waterways, and facilitating the appointment by city councils of personnel to

\footnotetext{
${ }^{45}$ Hippocrates' Airs, Waters, and Places was translated into Latin in the twelfth century: Biller, 'Proto-Racial Thought in Medieval Science', p. 161.

${ }^{46}$ Alcuin, 'Versus de patribus regibus et sanctis Euboricensis ecclesiae', ed. Godman, p. 6.

${ }^{47}$ Lucian of Chester, De laude Cestrie, ed. Taylor, p. 46.

${ }^{48}$ Opicinus de Canistris, Liber de laudibus civitatis Ticinensis, ed. Maiocchi and Quintavalle, p. 19.

${ }^{49}$ Bonvesin de la Riva, De magnalisbus Mediolani, ed. Pontiggia, pp. 186-188.

${ }^{50}$ Squatriti, Water and Society in Early Medieval Italy, pp. 30-33; Kucher, The Water Supply System of Siena.
} 
clean rivers. ${ }^{51}$ Almost all the panegyrics correspondingly emphasize the pleasing riparian situation of a particular city and its easy access to clean water. Conversely, stagnant waters were considered an all too likely site of pollution. ${ }^{52}$ The focus on the purity of the supply in Bonvesin de la Riva's praise of Milan clearly bespeaks the dangers of miasma arising from such a dangerous source: 'Are there are no putrid pools or lakes corrupting the air with their damp or stench? Certainly not! Here one finds clear fonts and fertile rivers.' ${ }^{, 53}$

More generally, the vital importance of having access to clean water through fountains, wells, and cisterns is underscored in encomia produced throughout the central and especially the late Middle Ages. ${ }^{54}$ The text attributed to Opicinus de Canistris celebrates the plenitude of wells and fountains in Pavia's public spaces, including a very beautiful and large vaulted fountain beneath the monastery church of St Thomas in the city centre. ${ }^{55}$ Again, Bonvesin de la Riva in particular elaborates on the water provisions in Milan, stating that the city trumped all others in its use not of cisterns or channels conveying water, but rather of large natural wells, offering direct access to clear and healthy fresh water. Corroborating the real efforts that were being made to share and distribute supplies, he adds that the wells were so abundant that every decent (decens) house had access to its own private well, in total numbering 6,000 springs. The supply was of such high quality that the light and savoury liquid, poured into wooden or glass containers, could promote a strong digestion 'through the

\footnotetext{
${ }^{51}$ See, in particular, Jørgenson, 'Local Government Responses to Urban River Pollution'; Keene, 'Issues of Water in Medieval London to c. 1300', p. 168; Trexler, 'Measures against Water Pollution in Fifteenth-Century Florence'.

${ }^{52}$ Rothauser, 'The Use of Water in the Medieval Consideration of Urban Space', p. 245; Allen, 'The Public Water Supply of Ipswich'.

${ }^{53}$ Bonvesin de la Riva, De magnalibus Mediolani, ed. Pontiggia, p. 30: 'Suntne ibi paludes aut lacus putride suis nebullis atque fetoribus aerem corrumptentes? Non certe; imo limpidi fontes et fertillia flumina.'

${ }^{54}$ Accordingly, in the later Middle Ages, civic councils imposed regulations on the use of public fountains, posting guards to protect them: Magnusson, Water Technology in the Middle Ages, p. 134. For William Fitzstephen's description of London's water supply, see Keene, 'Issues of Water in Medieval London to c. $1300^{\prime}$.

${ }^{55}$ Opicinus de Canistris, Liber de laudibus civitatis Ticinensis, ed. by Maiocchi and Quintavalle, p. 18. See Moses de Brolo, Liber Pergaminus, ed. Gorni, p. 449.
} 


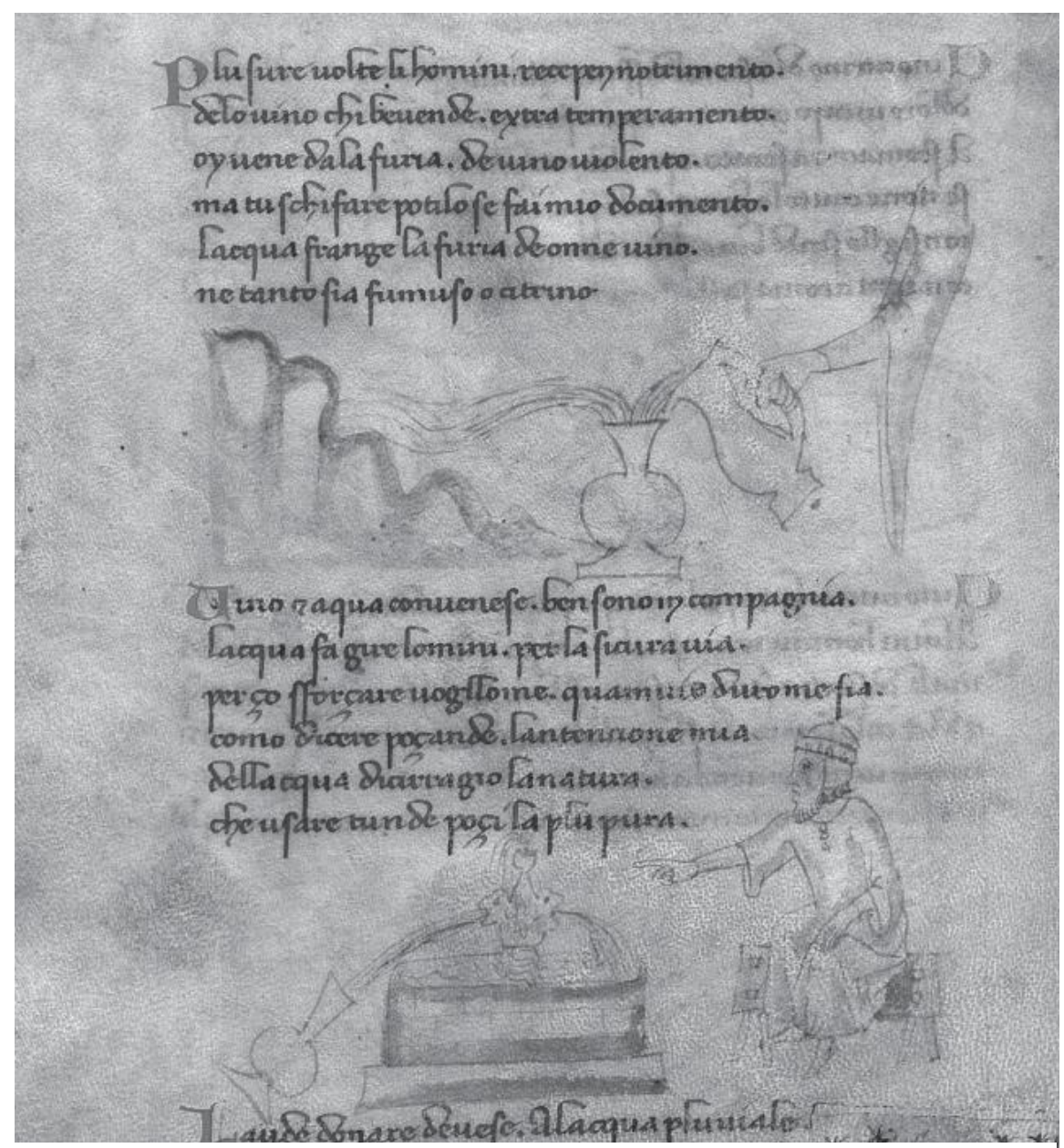

1.1. The benefits of pure water from a well-illustrated fourteenth-century vernacular regimen sanitatis

pores of the limbs'. ${ }^{56}$ Since antiquity, water had also been siphoned off for bathing purposes, as, for instance, the Laudes Mediolanensis civitatis dated to circa 738 attests. ${ }^{57}$ The Florentie urbis et reipublice descriptio, dated to 1339, similarly commends the sweet water of the Arno, which allowed each Florentine household to boast its own private well. On the other hand, the panegyric explains, the water in the suburbs was used for laundry and the cleaning of wool and other products. ${ }^{58}$ Finally, in his depiction of the Roman origins of Florence, Villani emphasizes that the third-century Roman emperor Macrinus had built aqueducts and conduits in order that the city might have plenty of pure water to drink and for cleansing the streets and

\footnotetext{
${ }^{56}$ Bonvesin de la Riva, De magnalibus Mediolani, ed. Pontiggia, p. 32: 'per poros membrorum'. See Boucheron, 'Water and Power in Milan, c. 1200-1500'. For efforts in medieval Siena to maintain the water supply system from the twelfth century onward, see Kucher, 'The Use of Water and its Regulation in Medieval Siena'.

${ }^{57}$ Laudes Mediolanensis civitatis, ed. Dümmler, I, p. 25.

${ }^{58}$ Florentie urbis et reipublice descriptio, ed. Frey, p. 120.
} 
gutters, as the water flowing to the Arno through canals equipped with drains rinsed the major thoroughfares on feast days. ${ }^{59}$

Water, however, was not just a natural resource necessary for hydration, transport, industry, and sanitation. From the twelfth century onwards, it was considered to have an additional aesthetic value that also benefited a person's health. As mentioned above, ancient Greek medical ideas lent considerable weight to assumptions concerning the impact of the olfactory and visual senses on health and wellbeing. ${ }^{60}$ Emphasis on a city's beauty and its well-positioned situation was thus undergirded by Greek intromission theory, which postulated that visible species or forms (images, phantasms, impressions) entered the body through the eyes, imprinting the form of the object viewed upon the viewer's senses. As a result, a direct relationship was said to exist between the object of vision and the viewer. ${ }^{61}$ Accordingly, whereas most encomia have something to say about the aesthetics of a city's environment (as do earlier geographical descriptions of territories and places, such as Bede's seventh-century panegyric of Britain), sources from the twelfth century onwards directly address the benefits of contemplating sites of beauty, sometimes expressly in medical terms. Gazing at greenery and clear pools of water in particular was regarded as a health-sustaining activity that refreshed the eyesight and the brain, especially of those weary from intensive reading. ${ }^{62}$ Bonvesin de la Riva clearly draws a relationship between the natural environment and the belief that pleasing sights could improve health, stating that, in addition to the direct medicinal use of plants in Milan, the flowers blossoming in the city refreshed the eyes, thereby rejuvenating an individual's eyesight and, through their wonderful smell, comforting the olfactory senses. ${ }^{63}$

Aesthetic experiences might also include the pleasures to be had from beautiful vistas. The same author, for instance, comments on the remarkable beauty of the plain (ratione pulcerimme planiciei) upon which Milan is situated. ${ }^{64}$ No less delightful is Jean de Jandun's early fourteenth-century description of Senlis, where the hilltops surrounding the city are said

\footnotetext{
${ }^{59}$ Giovanni Villani, Cronica, ed. Racheli, p. 20, cited by Frugoni, Distant City, pp. 59-60.

${ }^{60}$ Rawcliffe, “"Delectable Sightes and Fragrant Smelles”, pp. 7-12; Woolgar, The Senses in Late Medieval England.

${ }^{61}$ Akbari, Seeing through the Veil, Chapter two; and pp. 22-23 above.

${ }^{62}$ Rawcliffe, "“Delectable Sightes and Fragrant Smelles", pp. 11-12.

${ }^{63}$ Bonvesin de la Riva, De magnalibus Mediolani, ed. Pontiggia, p. 86.

${ }^{64}$ Bonvesin de la Riva, De magnalibus Mediolani, ed. Pontiggia, p. 34. See also Frugoni, Distant City, p. 112 , for a similar comment in Petrarch's description of Genoa, viewed from above.
} 
to offer stunning views and where bird song caresses the city dwellers' ears. ${ }^{65}$ William Fitzstephen's description of London's natural environment is just as acutely sensory. Here, he lovingly itemizes the:

[S]pacious and beautiful gardens of the citizens, and these are planted with trees.

Also there are on the north side pastures and pleasant meadow lands through which flow streams wherein the turning of mill-wheels makes a cheerful sound. [...] There are also outside London on the north side excellent suburban wells with sweet, wholesome and clear water that flows rippling over the bright stones. [...] These are frequented by great numbers and much visited by the students from the schools and by the young men of the city, when they go out for fresh air on summer evenings.

Good indeed is this city when it has a good lord! ${ }^{66}$

In a similar vein, the early thirteenth-century encyclopaedist and Franciscan friar Bartholomaeus Anglicus in his De proprietatibus rerum praised the benefits for scholars of the Parisian environment, its air, rivers, and encircling fields, claiming that the green meadows and streams refreshed philosophers' tired eyes. ${ }^{67}$ Lastly, for Leonardo Bruni, the surrounding woodlands, flowering meadows, river banks, and pools of clear water resembled a utopian paradise where the Florentines might feast their eyes on the panoramic views, and where the hills were full of laughter. ${ }^{68}$ Moreover, not only did the flowers delight the senses, they also helped to overpower bad odour or miasma. In times of plague, the inhabitants of crowded towns and cities were thus well-advised to surround themselves with fragrant

\footnotetext{
${ }^{65}$ Jean de Jandun, Tractatus de laudibus Parisius, ed. Le Roux de Lincy and Tisserand, p. 76. Music was considered to have a medicinal, therapeutic effect on the accidents of the soul: Jones, 'Music in the Later Middle Ages', pp. 121-125.

${ }^{66}$ William Fitzstephen, Descriptio nobilissimi civitatis Londoniae, ed. Robertson, III, p. 3; trans. Douglas and Greenaway, English Historical Documents, II, p. 957: 'Undique extra domos suburbanorum horti civium, arboribus consiti, spatiosi et speciosi, contigui habentur. Item a borea sunt agri, pascuae, et pratorum grata planities, aquis fluvialibus interfluis: ad quas molinorum versatiles rotae citantur cum murmure jocoso. [...] Sunt etiam circa Londoniam ab aquilone sub urbani fontes praecipui, aqua dulci, salubri, perspicua, et per claros rivo trepidante lapillus [...] et adeuntur celebriore accessu et majore freqnentia scholarium, et urbanse juventutis in serotinis aestivis ad auram exeuntis. Urbs sane bona, si bonum habeat dominum.'

${ }^{67}$ Bartholomaeus Anglicus, De proprietatibus rerum, XV, 'De Francia'. In Jean of Jandun's panegyric of Senlis, the fresh water, fruits, flowers, verdant colours, and smells presented a bountiful tableau for the visual senses: Jean de Jandun, Tractatus de laudibus Parisius, ed. Le Roux de Lincy and Tisserand, p. 76.

${ }^{68}$ Leonardo Bruni, Laudatio Florentinae urbis, ed. Baron, I, p. 234.
} 
flowers or greenery. ${ }^{69}$ The references in the later medieval panegyrics of William Fitzstephen, Opicinus de Canistris, Bonvesin de la Riva, and Jean de Jandun, the 1339 praise of Florence, and Leonardo Bruni to good climate and healthy air should be interpreted in this context, as clean air was considered a prerequisite for good health; and the environment ranked as one of most important of the non-naturals. We should, however, bear in mind that actual reality was presumably less agreeable, as, for instance, complaints about urination in public places in fifteenth-century Florence attest. ${ }^{70}$

Buttressed by good government, laws, and institutions, city dwellers might derive additional benefits from a healthy environment, which, according to Bonvesin de la Riva, also had a positive effect on population numbers, allowing both people and temporal goods to multiply. ${ }^{71}$ Bonvesin remarks with some satisfaction at the beginning of his encomium of 1288 that, because of 'its climate, its waters, its fertile and beautiful plain, Milan is situated in a wonderful location; shining proof of this is the fact that there are numerous elderly people, men and women, who live up to old age, and that the fertility of families, the population density and the prosperity of all good things miraculously increase day by day, by the grace of God'. ${ }^{72}$ These remarks are echoed in numerous political, medical, and religious observations about population numbers, fertility, and chastity in late medieval Italian cities, as Peter Biller has shown. ${ }^{73}$

\section{Civitas in civibus: urbanitas and environment}

Besides establishing the desirable features of urban infrastructure and the natural environment, the encomium also set the benchmark for collective civility, presenting an idealized image of the resident population that real inhabitants might aspire to. It is here that we may discern how health, hygiene, religious devotion, and urbanity come together, with status-enhancing civic virtues being embodied in urban communities, particularly as a result

\footnotetext{
${ }^{69}$ Rawcliffe, “"Delectable Sightes and Fragrant Smelles”, pp. 9-10.

${ }^{70}$ Biow, Culture of Cleanliness, p. 86.

${ }^{71}$ Bonvesin de la Riva, De magnalibus Mediolani, ed. Pontiggia, p. 104.

${ }^{72}$ Bonvesin de la Riva, De magnalibus Mediolani, ed. Pontiggia, p. 34: 'Est ergo ratione aeris, ratione aquarum, ratione fertilis atque pulcerrime planiciei, situ colocata mirabilli; cuius rei est fulgidum signum, quoniam quamplurimi senes grandevi et anus in etate ibi reperiuntur viventes decrepit, et etiam quia progeniei feconditas, populi frequentia, omnium bonorum prosperitas mirabilli modo quotidie per Dei gratiam perducitur in augumentum.'

${ }^{73}$ Biller, Measure of Multitude, pp. 385-417.
} 
of the benefits of living in a clean environment. Indeed, the panegyrics reveal a remarkable degree of uniformity in their emphasis on the virtuous character, dress, behaviour, and physical endowments of their respective subjects, each of these qualities pertaining to the 'honour' of the citizens, and by extension to the bonum commune and honour of the whole community. ${ }^{74}$ The encomia tend to focus in particular on the morality and fecundity of the female population (pudicitia matronali), which safeguarded the survival and 'pure lineage' of all. ${ }^{75}$ Virtuous civility was, moreover, according to the encomia, imbued with Christian values. From the early Middle Ages, the charitable nature of the people of Milan is thus praised, and nearly all encomia from this period remark upon the religious cityscape and the ubiquity of churches, in some cases alluding to the foundation of religious brotherhoods and the piety of the urban populace. In addition, two later medieval Italian encomia celebrate works of charity for the vulnerable within a specifically medical context. Bonvesin de la Riva boasts that Milan housed ten hospitals for the poor and sick; the Brolo, founded in 1145 by Goffredo de Bussero, in times of famine offering more than 500 clean beds, meals, and kindness to poor patients, and additional relief to an even greater number of indigents who were not bedridden. ${ }^{76}$ The Florentie urbis et reipublice descriptio of 1339 correspondingly commends the alms-giving populace and the hospitals in the city in the same breath as the installation of a new official whose task it was to ensure that men and women did not venture outdoors in indecent or sumptuous attire and make-up. ${ }^{77}$ Here, charity, care for the sick, and 'decent' behaviour are interconnected. Ultimately, as the twelfth-century Liber Pergaminus unequivocally states, the city where 'even the best houses, the fruits of hard toil, whether of rich man or poor, are made beautiful by a shared propriety', was a city of peaceful harmony, where laws reigned, as well as decorum, solidarity, and concord. ${ }^{78}$

Significantly, from the twelfth century onward, several encomia emphasize the fact that decency and urbanity evolved directly from a health-giving environment, in particular

\footnotetext{
${ }^{74}$ See Isenmann, 'Notion of the Common Good', p. 112, for the idea that Christian behaviour contributed to the honour and common good of the community.

${ }^{75}$ William Fitzstephen, Descriptio nobilissimi civitatis Londoniae, ed. Robertson, III, p. 4, likens the women to Sabines. Jean de Jandun, Tractatus de laudibus Parisius, ed. Le Roux de Lincy and Tisserand, p. 56, claims that the women of Paris mostly uphold the laws of marriage and are beyond repute. Florentie urbis et reipublice descriptio, ed. Frey, p. 122, mentions the fecundity of the female inhabitants.

${ }^{76}$ Bonvesin de la Riva, De magnalibus Mediolani, ed. Pontiggia, pp. 54, 56.

${ }^{77}$ Florentie urbis et reipublice descriptio, ed. Frey, p. 121.

${ }^{78}$ Moses de Brolo, Liber Pergaminus, ed. Gorni, p. 452.
} 
from the beneficial effects of clean air. Shaped by their temperate climate, the inhabitants of London are 'soft', not in the sense of being effeminate, but rather liberal and kind, not fierce or bestial, 'conspicuous above all others for their polished manners, for their dress and for the good tables that they keep'. Their courteous behaviour is comparable to that of barons rather than citizens, and they are accordingly good for their word. ${ }^{79}$ In the late twelfth-century $D e$ laude Cestrie, the populace's characteristics exemplify the 'English' temperament praised in contemporary poetry as sociable in feasting, lively at the table, generous, eloquent, free spirited, compassionate, and honest. ${ }^{80}$ These attributes are strongly reminiscent of the characteristics of the sanguine man, enumerated in the popular Regimen sanitatis Salernitanum; and, indeed, William Fitzstephen's flattering description of Londoners is directly preceded by a passage on the city's wholesome, fresh air, before he moves on to list its principal churches. Likewise, in Bonvesin's panegyric the inhabitants of Milan are said to live 'decenter, ordinate, magnicife', displaying generosity at home and abroad, and benign and honourable behaviour to all; their manners are elegant (facetus), their faces smiling, and they know nothing of deception. ${ }^{81}$ Jean de Jandun's early fourteenth-century description of Paris, with its implicitly Galenic emphasis on balance, likewise praises the moderation of Parisians, their 'charming affability, their urbanity, and the gentleness of their spirit' (decentis affabilitatis atque urbanitatis spirituali dulcedine gratiosi), although such all too lively characters, in the absence of a decent education, are likely to succumb to buffoonery. ${ }^{82}$

\section{Scripts for urban civility}

As mentioned at the beginning of this chapter, if the appropriation of 'urbanity' or civility might augment one's social status, the inhalation of clean, temperate air was to be recommended, as it appeared to engender a well-balanced temperament and invigorate the vital spirits. In addition, cheerful behaviour, decent dress, and attention to personal hygiene the avoidance of the spread of obnoxious odours and unseemly sights - were necessary

\footnotetext{
${ }^{79}$ William Fitzstephen, Descriptio nobilissimi civitatis Londoniae, ed. Robertson, III, p. 4; trans. Douglas and Greenaway, English Historical Documents, II, p. 957: 'prae omnibus aliis civibus ornatu morum, vestium, et mensae lautioris, spectabiles et noti habentur'.

${ }^{80}$ Lucian of Chester, De laude Cestrie, ed. Taylor, p. 65. For the similarities between the sanguine man and English stereotypes of urbanity, see Weeda, 'Images of Ethnicity', Chapter eight.

${ }^{81}$ Bonvesin de la Riva, De magnalibus Mediolani, ed. Pontiggia, p. 50.

${ }^{82}$ Jean de Jandun, Tractatus de laudibus Parisius, ed. Le Roux de Lincy and Tisserand, p. 54: 'decentis affabilitatis atque urbanitatis spirituali dulcedine gratiosi', trans. Berger, In Old Paris, p. 14.
} 
attributes in the pursuit of urbanitas. City dwellers with access to schools were accordingly drilled to make these traits their own, as a form of habitus. Conduct books, produced for educational purposes from the twelfth century onward, aided them in their social education by offering guides to acceptable behaviour. ${ }^{83}$ Some of them included prescripts on personal hygiene, partly drawing upon the same intellectual tradition as the more strictly healthfocused regimens such as the Regimen sanitatis Salernitanum. ${ }^{84}$ Thus, where William Fitzstephen's and Lucian's encomia praise the table manners of the citizenry, conduct manuals laid down specific rules on how to remain clean and avoid causing offence when eating, along lines previously set out by the physician Petrus Alphonsi.

Although conduct manuals first came into being in the particular context of the Catonian educational programme of schools for the clergy and aristocracy, from the thirteenth century they were also produced in an urban environment. One such text, known as De quinquaginta curialitatibus ad mensam, was in fact authored by the above-mentioned Bonvesin de la Riva in about 1260, in the vernacular Lombard language for schoolboys not yet proficient in Latin. In it, civility and hygiene are once more strongly connected. Bonvesin describes the urban man as courtly, friendly, cheerful, well-tempered, and gay (cortese, adorno, allegro e confortoso e fresco). ${ }^{85}$ Throughout the text he stresses the importance of moderation and self-discipline when eating and drinking, since they were believed to promote health by fostering humoral balance, as well as encouraging rest. ${ }^{86}$ The need for cleanliness is addressed extensively: hands are to be washed before and after dinner, and should, moreover, be kept clean and not dirtied by sticking them in ears or other orifices, or by stroking cats or dogs. As in the great majority of conduct books, he also prohibits spitting, blowing one's nose at the dinner table without a handkerchief, licking one's fingers, or cleaning one's teeth with them. Servants, too, must be clean; nor should they spit or defile table-wear or consumables. ${ }^{87}$ In his didactic poem De regimine et sapientia potestatis written c. 1240 about life behind the scenes at the podestà, Orfino da Lodi, who is mentioned in the panegyric of Lodi as a judge

\footnotetext{
${ }^{83}$ Gillingham, 'From Civilitas to Civility', pp. 269-281; Whelan, The Making of Manners and Morals in Twelfth-Century England; Jaeger, The Origins of Courtliness, pp. 166-168, 223-224; and Crouch, 'When Was Chivalry', discuss conduct literature in relation to courtliness.

${ }^{84}$ Weeda, 'Reviewing Conduct Books'. For health regimens, see Nicoud, Les régimes de santé au Moyen Age.

${ }^{85}$ Bonvesin de la Riva, La cinquanta cortesie, ed. Cantella and Magrassi, v, p. 29.

${ }^{86}$ Bonvesin de la Riva, La cinquanta cortesie, VII, XII, pp. 29, 33.

${ }^{87}$ Bonvesin de la Riva, La cinquanta cortesie, II, L, XXX-XXX, pp. 26, 45, 46, 58.
} 
and master of Latin poetry, ${ }^{88}$ also includes a lengthy chapter on personal hygiene and dining in an urban context, offering advice on hand-washing and the need to refrain from spitting. ${ }^{89}$ Some early Latin examples of conduct literature expressed great concern about hand-washing in medical terms, as, according to Greek-Arabic medical theory, dirty fingers might infect the eyes and damage a person's sight. For that reason, in his Disciplina clericalis Petrus Alphonsi urges his readers to wash their hands after dinner, because it was hygienic and well-mannered, and because eyes often sustained harm if they were wiped by hands that had been soiled while eating. $^{90}$

In this way, members of the civic elite were not only presented with a set of ideals pertaining to their environment, behaviour, and morality, but also instructed on how to perform in accordance to them. These conduct books offered status-enhancing scripts, which drew upon concepts of self-discipline and moderation that in part derived from concerns about health and hygiene. Adherence to these rules helped to shape the urbane, civilized, and hygienic man - as is apparent from the titles of two of the earliest conduct books, Daniel of Beccles' Urbanus magnus and the twelfth-century Latin text known as the Facetus. By extension, acquiring the habitus of urbanity offered access to the deliberative and decisionmaking councils of the urban body politic, where civilized prudentes, or wise men, issued bylaws regulating the use of the natural environment for the good and health of the entire political community.

However, there is an important caveat. For, as Bonvesin de la Riva remarks in his encomium of Milan, the question remains as to what extent all elements of the urban population might be able or willing to accumulate such physical and socio-cultural capital through the adoption of hygienic and civilized behaviour. And was it even desirable for them to do so? According to Bonvesin, a man ought only to acquire the wealth and dignity (expensas et honorem) appropriate to his station. Nonetheless, as a member of the tertiary order of the Humiliati, who wrote in the vernacular as well as in Latin, it is not implausible that Bonvesin himself originally came from an artisanal background in wool and textiles, and, as a successful social climber, ended his days in relative prosperity. ${ }^{91}$ Conceivably, the attainment of elite social status through the self-policing of the body and its environment may

\footnotetext{
${ }^{88}$ De laude civitatis laude, ed. Caretta, p. 60.

${ }^{89}$ Orfino da Lodi, De regimine et sapientia potestatis, ed. Pozzi, pp. 124-134.

${ }^{90}$ Petrus Alphonsi, Disciplina clericalis, ed. Hilka and Söderhjelm, XXVI, p. 40.

${ }^{91}$ Bonvesin de la Riva, De magnalibus Mediolani, ed. Pontiggia, p. 104.
} 
have paid off on certain occasions and in certain urban contexts, and persons from a similar social background to Bonvesin's would assuredly have been consumers of such aspirational literature. However, many factors and circumstances - including having access to these guides in the first place - mean that we have to resist the temptation to regard them as reflections of reality, or to assume that these ideals applied to, or were embraced by, the entire populace.

In addition, the performance of urbanity could be enhanced through endowments and other forms of charity lavished upon the poor and sick, together with financial contributions towards the construction and repair of civic infrastructure. For instance, on festive occasions and royal visits, streets and squares in England might be spruced up to appear at their most attractive, while water courses, such as the Great Conduit in London, ran with wine. ${ }^{92}$ This remarkable monument to civilitas, which was built in the first half of the thirteenth century in front of the house where Thomas Becket, the country's most celebrated saint was born, and which supplied fresh water to the public, was in part constructed as a charitable amenity for the urban community. ${ }^{93}$ Food was also handed out to the hungry; and donations, often made to hermits, for the maintenance of roads lying on important pilgrimage routes were regarded as good works celebrating the social community of the corpus christianum. ${ }^{94}$ Conversely, court fines imposed on miscreants included compulsory donations of stone for the upkeep of city walls or street paving. ${ }^{95}$ Transgressors might also be shamed in public and condemned to the pillory, their fate serving as both a threat to others and an uncompromising display of official authority. In this manner, the creation of a clean and salubrious environment was visibly associated with morality, and the violation of collective beliefs was punished not only financially, but also by assailing a person's sense of individual worth.

\section{Conclusion}

Painting an idealized cityscape, urban panegyrics, particularly from the twelfth century onwards, engaged with concepts of health and wellbeing that hinged, inter alia, upon the desirability of maintaining clean and aesthetically pleasing surroundings. The inhalation of pure air in particular was believed to enhance the virtue of urban communities, alongside

\footnotetext{
${ }^{92}$ Rawcliffe, Urban Bodies, pp. 38-39.

${ }^{93}$ Keene, 'Issues of Water in Medieval London to c. 1300', pp. 176-179.

${ }^{94}$ Sauer, 'Function of Material and Spiritual Roads'; Terpstra, Religious Refugees, p. 21.

${ }^{95}$ See pp. 139-141, 151-152 below.
} 
other factors, such as religious devotion and good government. City dwellers from the thirteenth century onward might also have access to conduct books extolling the benefits of urbane, hygienic behaviour. Thus, it was not just the judicial stick that was wielded to regulate and shape conduct pertaining to public health, since questions of personal status and fear of disease might equally well drive individuals to adhere to the accepted norms of health and hygiene through self-regulation.

The pursuit of high standards of personal hygiene and other efforts to preserve health were not, however, only viewed as beneficial to the individual; they were also, at least at a theoretical level, regarded as an integral element of the wellbeing of the entire community, conceived metaphorically as the body politic. Just as, according to Galenic humoral theory, good health was contingent on the harmonious interaction between bodily parts, in political treatises and regimens the key concept for society and the economy at large was balance or 'proportional equalization' (aequalitas temperantia). ${ }^{96}$ The inheritance of the Ancient Greek and Biblical concept of society as a body that should strive to maintain this state of equilibrium led to an early biopolitical conceptualization of power, in which the political body itself was viewed as the sum of the health of the individual parts, whose cooperation in a hierarchical system guaranteed collective well-being. Governing the body politic consequently involved the imposition of a regime in which individual health engaged with the health of the entire community. The concept of equilibrium is reflected in the medieval panegyric itself, which was believed to present a balanced description of all parts of urban society. The conceptualization of society as a harmonious corporate entity had a broad application, which is reflected not only in the increased production of the manuals concerning individual social behaviour discussed above, but also, for instance, in the popularity of regimens scripting personal health (such as the Regimen sanitatis Salernitanum) $;{ }^{97}$ of regimens for rulers (for example, Giles de Rome's De regimine principum); and regimens of urban governance (such as John of Viterbo's Liber de regimine civitatum). As a result, political tracts and health regimes engaged in an increasingly referential dialogue, which

\footnotetext{
${ }^{96}$ Kaye, History of Balance, pp. 128-240. The concept of equilibrium might extend to the textual composition of the urban panegyric, as for example in the case of Bruni's early fifteenth-century encomium Laudatio Florentinae urbis. Here, the city itself is the sum of its constituent parts: Hyde, 'Medieval Descriptions of Cities', p. 309.

${ }^{97}$ Nicoud, Les régimes de santé au Moyen Age.
} 
becomes clear when one considers the overlapping terminology of regime, regimen, polity and policing. ${ }^{98}$

The other side of the coin was that the increasing indexation of healthy or insanitary behaviour and distinct bodily types - for instance the melancholic, dark Jew or the diseased poor - could, on occasion, encourage social Othering. It is perhaps relevant, in this regard, that the later Middle Ages witnessed a surge in violence against minorities, and has, indeed, been characterized as a 'persecuting society'. The pursuit of high standards of social hygiene did not always entail an absolute rejection of minorities in theoretical texts, however, as the concept of equilibrium underlying the metaphor of the body politic involved the maintenance of a precarious balance between its 'lesser' and 'better' members. In practice, too, as many contributions to this volume attest, urban interventions at times display an inclusiveness and practical commitment to the principles of Christian charity that should qualify our assumptions about the rigidity of medieval Othering. Rather than undertaking a single-minded and essentially simplistic quest for the recovery of pre-lapsarian purity, particular emphasis was laid in this literature on ideals of temperance, self-control, moderation, the triumph of reason over passion, modesty, and considerateness. Fundamental in this regard was the order, consistency, and self-discipline that decorum imposed on personal behaviour, both in deeds and speech. Such 'decorum' the rhetorician Cicero, many centuries earlier, had likened to the physical beauty of the harmonious symmetry of limbs - a far cry from the popular image of medieval chaos, danger, and filth constructed in modern times. ${ }^{99}$

\footnotetext{
${ }^{98}$ Kotkas, Royal Police Ordinances, p. 1.

${ }^{99}$ Jaeger, The Origins of Courtliness, p. 116.
} 


\section{BIBLIOGRAPHY}

\section{Printed primary sources}

Alcuin, 'Versus de patribus regibus et sanctis Euboricensis ecclesiae', ed. by Peter Godman, Alcuin: The Bishops, Kings, and Saints of York (Oxford: Clarendon Press, 1982)

Anonymi Mediolansis Libellus, ed. by A. and G. Colombo (Bologna: Rerum Italicarum scriptores, I, 2, 1725)

Benzo d'Alessandria, De Mediolano Florentissima civitate, ed. by L.A. Ferrai, Bollettino dell'Istituto Storico Italiano, 9 (1890), 15-36

Bonvesin de la Riva, De magnalibus Mediolani, ed. by Giuseppe Pontiggia (Milan: Bompiani, 1974)

Bonvesin de la Riva, La cinquanta cortesie de tavola, ed. by Mario Cantella and Donatella Magrassi (Milan: La Spiga, 1985)

Bruni, Leonardo, 'Laudatio', ed. by Hans Baron, From Petrarch to Leonardo Bruni: Studies in Humanistic and Political Literature (Chicago and London: Chicago University Press, 1968)

Bruni, Leonardo, 'Panegyric to the City of Florence', trans. by Benjamin G. Kohl, ed. by Benjamin G. Kohl and Ronald G. Witt, The Earthly Republic: Italian Humanists on Government and Society (Manchester: Manchester University Press, 1978)

English Historical Documents, II, 1042-1189, ed. and trans. by D.C. Douglas and G.W. Greenaway (Oxford: Oxford University Press, 1981)

Fitzstephen, William, Descriptio Nobilissimae Civitatis Londoniae, ed. by James C. Robertson, Materials for the history of Thomas Becket, Archbishop of Canterbury, 7 vols. (London: Rerum Britannicarum medii aevi scriptores, 67, 1877)

'Florentie urbis et reipublice descriptio', ed. by C. Frey, Die Loggia dei Lanzi zu Florenz: Eine quellenkritische Untersuchung (Berlin: Verlag Wilhelm Hertz, 1885)

Graphia aureae urbis Rome, ed. by P.E. Schramm, Kaiser, Könige und Päpste: Gesammelte Aufsätze zur Geschichte des Mittelalters, 5 vols. (Stuttgart: Hiersemann, 1969-1971, 1975) 
Jean de Jandun, Tractatus de laudibus Parisius, Deux éloges de la ville de Paris, ed. by Antoine J.V. Le Roux de Lancy and Lazare M. Tisserand, Paris et ses historiens au XIV et XVe siècles (Paris: Imprimerie impériale, 1867)

Jean de Jandun, Tractatus de laudibus Parisius, ed. and trans. by Robert W. Berger, In Old Paris: An Anthology of Source Descriptions, 1323-1790 (New York: Italica Press, 2002)

'Laudes Mediolanensis civitatis', ed. by E. Dümmler, Poetae Latini aevi Carolini, 5 vols. (Berlin: Monumenta Germaniae Historica, 1881)

'Laudes Veronensis civitatis', ed. by. E. Dümmler, Poetae Latini aevi Carolini, 5 vols. (Berlin: Monumenta Germaniae Historica, 1881)

Lucian of Chester, Liber Luciani de laude Cestrie, ed. by M.V. Taylor (Edinburgh: Lancashire and Cheshire Record Society, 64, 1912)

Master Gregory, De mirabilibus urbis Rome, ed. by R. Valentini and G. Zucchetti, Codice topografico della citta di Roma, 4 vols. (Rome: s. n., 1940-1953)

Moses de Brolo, Liber Pergaminus, ed. by G. Gorni, 'Il "Liber Pergaminus" di Mosè de Brolo', Studi Medievali, 9 (1970), 440-56

Opicinus de Canistris, Liber de laudibus civitatis Ticinensis, ed. by Rodolfo Maiocchi and Ferruccio Quintavalle (Città di Castello: Lapi, 1903)

Orfino da Lodi, De laude civitatis laude, ed. by Alessandro Caretta (Lodi: n. p., 1962)

Paul the Deacon or Paulinus of Aquileia, 'Versus de destructione Aquileiae', ed. by E.

Dümmler, Poetae Latini aevi Carolini, 5 vols. (Berlin: Monumenta Germaniae Historica, 1, 1881)

Petrus Alphonsi, Disciplina clericalis, ed. by Alfons Hilka and Werner Söderhjelm, Die Disciplina clericalis des Petrus Alphonsi: Das älteste Novellenbuch des Mittelalters (Heidelberg: Carl Winter's Universitätsbuchhandlung, 1911)

Villani, Giovanni, Cronica, ed. by A. Racheli (Trieste: Lloyd Austriaco, 1857)

\section{Printed secondary sources}


Akbari, Suzanne Conklin, Seeing through the Veil: Optical Theory and Medieval Allegory (Toronto and London: University of Toronto Press, 2004)

Allen, David, 'The Public Water Supply of Ipswich before the Municipal Corporation Act', Proceedings of the Suffolk Institute of Archaeology, 40 (2001), 31-54

Ashenburg, Katherine, The Dirt on Clean: An Unsanitized History (New York: Vintage Canada, 2008)

Balestracci, Duccio, 'The Regulation of Public Health in Italian Medieval Towns', in Die Vielfalt der Dinge: Neue Wege zur Analyse mittelaltericher Sachkultur, ed. by Harry Kühnel and others (Vienna: Verlag der Österreischischen Akademie der Wissenschaften, 1998), pp. $345-357$

Baron, Hans, 'Leonardo Bruni: “Professional Rhetorician” or “Civic Humanist”?', Past \& Present, 36 (1967), 21-37

Biller, Peter, The Measure of Multitude: Population in Medieval Thought (Oxford: Oxford University Press, 2000)

Biller, Peter, 'Proto-Racial Thought in Medieval Science', in The Origins of Racism in the West, ed. by Miriam Eliav-Feldon and others (Cambridge: Cambridge University Press, 2009), pp. 157-180

Bocchi, Francesca, 'Regulation of the Urban Environment by the Italian Communes from the Twelfth to the Fourteenth Century', Bulletin of the John Rylands Library, 72 (1990), 63-78

Biow, Douglas, The Culture of Cleanliness in Renaissance Italy (Ithaca: Cornell University Press, 2006)

Boucheron, Patrick, 'Water and power in Milan, c. 1200-1500', Urban History, 28 (2000), 180-193

Bourdieu, Pierre, Opstellen over smaak, habitus en het veldbegrip, ed. by Dick Pels and trans. by Rokus Hofstede (Amsterdam: Van Gennep, 1989)

Bourdieu, Pierre, Outline of a Theory of Practice (Cambridge: Cambridge University Press, 1977) 
Catto, Jeremy, 'Andrew Horn (c.1275-1328)', in Oxford Dictionary of National Biography (Oxford: Oxford University Press, 2004) [http://www.oxforddnb.com/view/article/13780, accessed 23 July 2017]

Carruthers, Mary, Craft of Thought: Meditation, Rhetoric, and the Making of Images, 4001200 (Cambridge: Cambridge University Press, 1998)

Ciecieznski, N.J., 'The Stench of Disease: Public Health and the Environment in LateMedieval English Towns and Cities', Health, Culture and Society, 4 (2013), 92-104

Classen, Carl Joachim, Die Stadt im Spiegel der 'Descriptiones' und 'Laudes Urbium' in der antiken und mittelalterlischen Literatur bis zum Ende des zwölften Jahrhunderts (Hildesheim and New York: Olms, 1980)

Cohn, Samuel Kline, Cultures of Plague: Medical Thinking at the End of the Renaissance (Oxford: Oxford University Press, 2010)

Coomans, Janna, and Geltner, G., 'On the Street and in the Bathhouse: Medieval Galenism in Action?', Añuario de Estudios Medievales, 43 (2013), 53-82

Coudert, Allison P., 'Sewers, Cesspools, and Privies: Waste as Reality and Metaphor in PreModern European Cities', in Urban Space in the Middle Ages and the Early Modern Age, ed. by Albrecht Classen (Berlin: Walter de Gruyter, 2009), pp. 713-734

Crouch, David, 'When was Chivalry', in Chivalric Identity in the Middle Ages, ed. by D. Crouch and J. Deploige (Leuven: Medievalia Lovaniensia, 2018), forthcoming

Demaitre, Luke, Medieval Medicine: The Art of Healing, from Head to Toe (Santa Barbara: Praeger, 2013)

Van Dijk, 'Soap is the Onset of Civilization', in Cleanliness and Culture: Indonesian Histories, ed. by C. van Dijk and G. Gelman Taylor (Leiden: KITLV Press, 2011), pp. 1-39 Douglas, Mary, Natural Symbols (Hoboken: Taylor and Francis, 2002)

Epstein, Steven A., Purity Lost: Transgressing Boundaries in the Eastern Mediterranean, 1000-1400 (Baltimore: Johns Hopkins University Press, 2007) 
Fasoli, Gina, 'La coscienza civica nelle Laudes civitatum', in La coscienza cittadina nei comuni italiani del Duecento (Todi: Accademia Tedertina, 1972), pp. 9-44

Foucault, Michel, 'The Political Function of the Intellectual', Radical Philosophy, 17 (1977), 126-133

Frugoni, Chiara Settis, Distant City: Images of Urban Experience in the Medieval World (Princeton: Princeton University Press, 1991)

García-Ballester, Luis, 'On the Origins of the Six Non-Natural Things in Galen', in Galen und das hellenistische Erbe: Verhandlungen des IV. Internationalen Galen-Symposiums veranstaltet vom Institut für Geschichte der Medizin am Bereich Medizin (Charité) der Humboldt-Universität zu Berlin 18.-20. September 1989, ed. by J. Kollesch and D. Nickel (Stuttgart: Franz Steiner Verlag, 1993), pp. 105-115

Geltner, G., 'Public Health and the Pre-Modern City: A Research Agenda', History Compass, 10 (2012), 231-245

Geltner, G., 'Healthscaping a Medieval City: The Curia viarum of Lucca and the Future of Public Health History', Urban History, 40 (2013), 395-415

Geltner, G., 'Finding Matter out of Place: Bologna's 'Dirt' (Fango) Officials in the History of Premodern Public Health', in The Far-Sighted Gaze of Capital Cities: Essays in Honor of Francesca Bocchi, ed. by Rosa Smurra and others (Rome: Viella, 2014), pp. 307-321 Gillingham, John, 'From Civilitas to Civility: Codes of Manners in Medieval and Early Modern England', Transactions of the Royal Historical Society, 12 (2002), 267-289

Hankins, James, Plato in the Italian Renaissance, 2 vols. (Leiden: Brill, 1990)

Henderson, John, 'Public Health, Pollution and the Problem of Waste Disposal in Early Modern Tuscany', in Le interazioni fra economia e ambiente biologico nell'Europa preindustriale secc. XIII-XVIII, ed. by Simonetta Cavaciocchi (Florence: Florence University Press, 2010), pp. 373-382

Hyde, J.K., 'Medieval Descriptions of Cities', Bulletin of the John Rylands Library, 48 (1966), 308-340 
Inglis, Erik, 'Gothic Architecture and a Scholastic: Jean de Jandun's Tractatus de laudibus Parisius (1323)', Gesta, 42 (2003), 63-85

Isenmann, Eberhard, 'The Notion of the Common Good, the Concept of Politics, and Practical Policies in Late Medieval and Early Modern German Cities', in De Bono Communi: The Discourse and Practice of the Common Good in the European City (13th-16th C.), ed. by Elodie Lecuppre-Desjardin and Anne-Laure Van Bruaene (Turnhout: Brepols, 2010), pp. 107148

Jaeger, C. Stephen, The Origins of Courtliness: Civilizing Trends and the Formation of Courtly Ideals, 923-1210 (Philadelphia: University of Pennsylvania Press, 1985)

Jones, Peter Murray, 'Music in the Later Middle Ages: The Case of Hugo van der Goes', in Music as Medicine: The History of Music Therapy since Antiquity, ed. by Peregrine Horden (Farnham: Ashgate, 2000), pp. 120-144

Jørgensen, Dolly, 'Cooperative Sanitation: Managing Streets and Gutters in Late Medieval England and Scandinavia', Technology and Culture, 49 (2008), 547-567

Jørgensen, Dolly, “"All good rule of the citee”: Sanitation and Civic Government in England, 1400-1600', Journal of Urban History, 36 (2010), 300-315

Jørgenson, Dolly, 'Local Government Responses to Urban River Pollution in Late Medieval England', Water History, 2 (2010), 35-52

Jørgensen, Dolly, 'Modernity and Medieval Muck', Nature and Culture, 3 (2014), 225-237

Kaye, Joel, A History of Balance 1250-1375: The Emergence of a New Model of Equilibrium and its Impact on Thought (Cambridge: Cambridge University Press, 2014)

Keene, Derek, 'Issues of Water in Medieval London to c. 1300', Urban History, 28 (2001), $161-179$

Keene, Derek, 'The Medieval Urban Environment in Documentary Records', Archives, 16 (1983), 137-144

Kotkas, Toomas, Royal Police Ordinances in Early Modern Sweden (Leiden: Brill, 2014) 
Kucher, Michael P., 'The Use of Water and its Regulation in Medieval Siena', Journal of Urban History, 31 (2005), 504-536

Kucher, Michael P., The Water Supply System of Siena, Italy: The Medieval Roots of the Modern Networked City (London and New York: Routledge, 2005)

Kwakman, Carla, 'Slijkburgers in Utrecht', Madoc: Tijdschrift over de Middeleeuwen, 19 (2005), 167-174

Magnusson, Roberta J., 'Medieval Urban Environmental History', History Compass, 11 (2013), 189-200

Magnusson, Roberta J., Water Technology in the Middle Ages: Cities, Monasteries, and Waterworks after the Roman Empire (Baltimore and London: Johns Hopkins University Press, 2003)

McVaugh, Michael R., Medicine before the Plague: Practitioners and their Patients in the Crown of Aragon, 1285-1345 (Cambridge: Cambridge University Press, 1993)

Mikkeli, Heikki, Hygiene in the Early Modern Medical Tradition (Helsinki: Academia Scientiarum Fennica, 1999)

Nederman, Cary J., 'Nature, Ethics, and the Doctrine of "Habitus": Aristotelian Moral Psychology in the Twelfth-Century', Traditio, 45 (1989-90), 87-110

Nicoud, Marilyn, Les régimes de santé au Moyen Âge: Naissance et diffusion d'une écriture médicale, XIIIe-XVe siècle, 2 vols. (Rome: École française de Rome, 2007)

Rather, L.J., 'The Six Things Non-Natural: A Note on the Origins and Fate of a Doctrine and a Phrase', Clio Medica, 3 (1968), 337-347

Rawcliffe, Carole, "Delectable Sightes and Fragrant Smelles": Gardens and Health in Late Medieval and Early Modern England', Garden History, 36 (2008), 3-21 
Rawcliffe, Carole, 'Sources for the Study of Public Health in the Medieval City', in Understanding Medieval Primary Sources, ed. by Joel T. Rosenthal (London and New York: Routledge, 2012), pp. 177-195

Rawcliffe, Carole, Urban Bodies: Communal Health in Late Medieval English Towns and Cities (Woodbridge: Boydell, 2013)

Rothauser, Britt C.L., 'A Reurer ... Brighter Pen boPe the Sunne and Mone: The Use of Water in the Medieval Consideration of Urban Space', in Urban Space in the Middle Ages and the Early Modern Age, ed. by Albrecht Classen (Berlin: Walter de Gruyter, 2009), pp. 245-272

Ruth, Jeffrey S., Urban Honor in Spain: The Laus Urbis from Antiquity Through Humanism (Lewiston: Edwin Mellen Press, 2011)

Sabine, Ernest, L., 'City Cleaning in Mediaeval London', Speculum, 12 (1937), 19-43

Sauer, Michelle M., 'The Function of Material and Spiritual Roads in the English Eremitic. Tradition', in Roadworks: Medieval Britain, Medieval Roads, ed. by Valerie Allen and Ruth Evans (Manchester: Manchester University Press, 2016), pp. 201-224

Scattergood, John, 'Misrepresenting the City: Genre, Intertextuality, and William Fitz Stephen's Description of London (c. 1173)', in London and Europe in the Later Middle Ages, ed. by Julia Boffey and Pamela King (London: Centre for Medieval and Renaissance Studies, Queen Mary and Westfield College, University of London, 1995), pp. 1-34

Schmidt, Hans-Joachim, 'Societas Christiana in civitate: Städtekritik und Städtelob im 12. und 13. Jahrhundert', Historische Zeitschrift, 257 (1993), 297-354

Seigel, Jerrold, 'Civic Humanism or Ciceronian Rhetoric?', Past \& Present, 34 (1966), 3-48

Shaw, Diane, 'The Construction of the Private in Medieval London', Journal of Medieval and Early Modern Studies, 26 (1996), 447-466 
Squatriti, Paolo, Water and Society in Early Medieval Italy, AD 400-1000 (Cambridge:

Cambridge University Press, 1998)

Terpstra, Nicholas, Religious Refugees in the Early Modern World: An Alternative History of the Reformation (Cambridge: Cambridge University Press, 2015)

Thorndike, Lynn, 'Sanitation, Baths, and Street-Cleaning in the Middle Ages and Renaissance', Speculum, 3 (1928), 192-203

Tolan, John Victor, Peter Alfonsi and his Medieval Readers (Gainesville: University of Florida Press, 1993)

Trexler, Richard C., 'Measures against Water Pollution in Fifteenth-Century Florence', Viator, 5 (1974), 455-467

Turning, Patricia, Municipal Officials, their Public, and the Negotiation of Justice in Medieval Languedoc: Fear Not the Madness of the Raging Mob (Leiden: Brill, 2012)

Siraisi, Nancy G., Medieval and Early Renaissance Medicine: An Introduction to Knowledge and Practice (Chicago: Chicago University Press, 1990)

Vigarello, Georges, Concepts of Cleanlines: Changing Attitudes in France since the Middle Ages (Cambridge: Cambridge University Press, 1988)

Weeda, Claire, 'Reviewing Conduct Books: Galenic Medicine and the "Civilizing Process" in Western European Households c. 1100-1300', in The Great Household, 1000-1500:

Proceedings of the 2016 Harlaxton Symposium, ed. by C.M. Woolgar (Woodbridge: Boydell, 2018), pp. 167-184

Whelan, Fiona, The Making of Manners and Morals in Twelfth-Century England: The Book of the Civilised Man (Abingdon: Routledge, 2017)

Woolgar, C.M., The Senses in Late Medieval England (New Haven: Yale University Press, 2006) 
Zanna, Paolo, “"Descriptiones urbium” and Elegy in Latin and Vernaculars in the Early Middle Ages', Studi Medievali, 32 (1991), 523-596

Zotz, Thomas, 'Urbanitas in der Kultur des westlichen Mittelalters: Höfische Wertvorstellung im Umfeld von elegantia morum und elegantia corporis', Frühmittelalterliche Studien, 45 (2011), 295-308

\section{About the author}

Claire Weeda is a cultural historian whose main fields of interest include ethnic stereotyping, medicine, and the body politic in later medieval Europe. She has published in various international journals on ethnic identity, religion, medicine, and socio-cultural indexation, and co-edited Imagining Communities: Historical Reflections on the Process of Community Formation (2018). She is currently Assistant Professor of Medieval History at Leiden University and is conducting research on public health and organic politics in the period 1100-1500. 